\title{
Menuju Beragama Secara Swalayan
}

\author{
Yusdani \\ Universitas Islam Indonesia Yogyakarta
}

The article investigates Islam as revealed religion, because it originates from Allah. The problem is that when Islam is interpreted by Moslems, the pluralism of Islam, including in Indonesia, emerges. This pluralism is caused by the influence of various factors, such as sociological, cultural, and intellectual ones. This can be called as the aesthetics of reception, and Islam itself denotes as poly-interpretable religion. Departing from such pluralism in understanding Islam, Indonesian Moslems should develop the tolerant attitude, not only among Moslems, but also between them and the followers of other religions.

Keywords: Islam, revealed religion, pluralism, aesthetic reception, tolerant.

lisien slam sebagai suatu ajaran tentang kehidupan manusia merupakan suatu pandangan yang tidak diperdebatkan lagi di kalangan kaum muslimin, akan tetapi bagaimana Islam itu dipahami dan diterapkan oleh pemeluknya dalam kehidupan, dalam konteks inilah, terletak persoalan yang sebenarnya (Rahman, 1966 : 101). Karena Islam sebagai ajaran itu satu (tunggal) tetapi polyinterpretable ( pemahaman terhadap Islam itu beragam ).

Munculnya interpretasi yang beragam terhadap Islam tersebut disebabkan oleh berbagai faktor. Ada sejumlah faktor yang mempengaruhi dan membentuk pemahaman kaum muslim terhadap Islam. Situasi sosiologis, kultural, dan intelektual, atau apa yang disebut Arkoun (1988) sebagai estetika penerimaan (aesthetics of reception), sangat berpengaruh dalam menentukan bentuk dan isi pemahaman. Kecenderungan intelektual yang berbeda-apakah motifnya untuk mengetahui makna doktrin yang sebenarnya, yang secara literer terekspresikan dalam teks, atau untuk mengetahui prinsip- prinsip umum dari suatu doktrin, di luar ekspresi literer dan tekstualnya (Gibbons, 1987:1-31) dalam upaya untuk memahami Islam dapat berujung pada pemahaman yang beragam mengenai suatu doktrin. Karenanya, kendatipun setiap Muslim menerima prinsip-prinsip umum yang tertuang dalam Islam, pemahaman mereka tentang ajaran Islam diwarnai perbedaanperbedaan.

Munculnya berbagai aliran (mazhab) dalam lapangan fiqh, teologi, filsafat, dan lain-lain dalam Islam, misalnya, menunjukkan bahwa ajaran-ajaran Islam itu, multiinterpretatif - banyak penafsiran (Hodgson, 1974). Watak multiinterpretatif ini telah berperan sebagai dasar dari kelenturan Islam dalam sejarah. Di samping itu, karakteristik ajaran yang multiinterpretatif ini juga mengisyaratkan keharusan pluralitas dalam tradisi Islam. Karena itu, sebagaimana telah dikatakan oleh banyak pihak, Islam tidak dapat dan tidak seharusnya dilihat dan dipahami secara monolitik (Ayoob, 1981). Hal ini mengindikasikan Is- 
lam yang empirik dan aktual-karena berbagai perbedaan dalam konteks sosial, ekonomi, dan politik akan berarti lain lagi bagi orang Islam lainnya (Ayubi, 1991: 60-64).

Kerangka pemahaman bahwa Islam sebagai doktrin Tuhan itu satu tetapi polyinterpretable yang disebabkan berbagai faktor di atas, perlu disegarkan kembali untuk memahami dinamika dan pluralitas pemikiran Islam di Indonesia kontemporer sekarang ini ( Wijdan, Yusdani,dkk, 2007: 105-106). Hal ini urgen dilakukan agar kaum muslimin penuh kearifan dalam menyikapi fenomena perbedaan pemahaman dan keberagamaan yang kadang-kadang menyeruak ke permukaan.

\section{Realitas Kemajemukan Sebagai Fakta}

Untuk memahami pemikiran Islam di Indonesia kontemporer sekarang ini, tidak dapat dilepaskan dari Islam sebagai agama yang hidup di tengah umat. Sebagai agama yang hidup di tengah umat, wawasan pemikiran keislaman dan keagamaan umat Islam mengalami perubahan dan pergeseran di sana sini, karena perubahan dan perbedaan tantangan, peluang dan persoalan yang dihadapi. Dalam era globalisasi ilmu dan budaya, hampir semua sendi-sendi kehidupan umat manusia mengalami perubahan yang amat dahsyat, institusi sosial-kemasyarakatan, kenegaraan, keluarga, bahkan tidak terkecuali institusi dan pemikiran keagamaan tidak luput dari pengaruh arus globalisasi ini (Abdullah, 1994: 169-170).

Sebagai konsekuensi logis dari kehidupan yang selalu berubah tersebut adalah bahwa idiom, kosakata, pertanyaan yang mendasar, falsafah hidup, keprihatinan, pemikiran dan gagasan, pola tingkah laku, dan mekanisme kerja, semuanya ikut berubah. Pada saat yang sama, pengetahuan manusia tentang realitas jagat raya ini baik yang menyangkut dunia fisika, kosmologi juga berkembang pesat sesuai dengan tingkat laju pertumbuhan dan perkembangan laboratorium ilmu pengetahuan baik dalam bidang astronomi, biologi, bioteknologi dan lain-lainnya. Perubahan tingkat pertumbuhan perekonomian suatu bangsa juga ikut merubah cara pandang bangsa tersebut terhadap realitas dunia (Abdullah, 1994: 170).

Penjelasan di atas menunjukkan bahwa, mustahil rasanya jika corak dan nuansa pemikiran keagamaan dan keislaman tidak ikut berubah seiring dengan arus perubahan yang terjadi. Agaknya tidak sepenuhnya tepat untuk mengatakan bahwa tantangan dan peluang yang dihadapi kaum muslimin Indonesia sekarang, terutama dalam hal wawasan pemikiran keagamaan adalah sama saja dengan masa-masa sebelumnya, atau tidak mengalami perubahan, sehingga perlu diadakan peninjauan ulang, reorientasi, modifikasi, penajaman atau pengurangan pada bagian-bagian tertentu (Abdullah, 1994: 169-170).

Dampak positif dari munculnya pluralitas pemikiran keagamaan baik secara organisasi maupun individual dalam berbagai bentuknya tersebut adalah bahwa khazanah pemikiran keislaman di Indonesia semakin menyediakan banyak pilihan dan ini secara tidak langsung mendorong munculnya pluralitas pemikiran. Dengan munculnya beragam pemikiran individual, maka pluralitas pemikiran tersebut terasa lebih semarak. Paling tidak, kondisi ini memberi alternatif ventilasi-ventilasi pemikiran yang kaya (Abdullah, 1995: 70-71).

Realitas dan fenomena kemajemukan, baik dalam paham keagamaan maupun dalam sosial keagamaan sejalan dengan kemajemukan masyarakat Indonesia itu 
sendiri, atas dasar suku bangsa, bahasa, dan agama. Segmentasi umat Islam di Indonesia antara lain mempunyai dimensi yang bersifat kultural, yaitu bahwa keragaman kelompok umat Islam mempunyai latar belakang budaya keagamaan (religiokultural) yang relatif berbeda, sejalan dengan perbedaan latar belakang budaya - kemasyarakatan (sosio-kultural) mereka.

Ormas-ormas Islam, terutama yang lahir pada masa pra-kemerdekaan, memiliki hubungan yang erat dengan budaya di mana ormas tersebut lahir dan berkembang. Bahkan, sebuah organisasi dapat menampilkan wajah yang berbeda sesuai dengan lingkungan di mana organisasi tersebut hidup. Corak paham keagamaan di kalangan ormas-ormas Islam ini tidaklah sematamata merupakan hasil pemahaman terhadap (sumber-sumber) Islam, tetapi juga merupakan hasil pengaruh dari lingkungan budaya lokal.

Pengaruh latar belakang budaya lokal di atas dapat diamati, umpamanya pada kecenderungan masing-masing pendiri NU dan Muhammadiyah. KH Hasyim Asy'ari, pendiri NU yang hidup di lingkungan budaya santri yang kuat di Jombang, menawarkan model pendekatan terhadap Islamisasi yang dapat disebut santrinisasi santri. Sedangkan $\mathrm{KH}$ Ahmad Dahlan, pendiri Muhammadiyah, yang hidup di lingkungan budaya priyayi di Kauman Yogyakarta, menawarkan model pendekatan yang dapat disebut santrinisasi priyayi atau priyayisasi santri ( Syamsuddin, 1992:4).

Kedua pendekatan tersebut di atas memiliki logika sendiri. Baik Ahmad Dahlan maupun Hasyim Asy'ari, telah memberikan yang terbaik bagi pengembangan Islam yang relevan dengan setting kultural yang mereka hadapi. Kedua organisasi yang mereka lahirkan merupakan dua sayap penting bagi perkembangan paham keislaman di Indonesia ( Syamsuddin, 1992:4).
Pembahasan tentang pemikiran sosial keagamaan yang dikembangkan oleh berbagai organisasi ke-Islaman di Indonesia seperti Muhammadiyah, NU dan lain sebagainya telah banyak publikasi yang menelaahnya, tetapi munculnya pemikiran Islam di Indonesia yang dikembangkan oleh individu pasca Muhammadiyah dan NU belum begitu banyak dipetakan. Oleh karena itu, penting dideskripsikan tentang pemikiran Islam individu dan bagaimana wujud pemikiran itu telah dituangkan oleh tokoh-tokohnya. Untuk memudahkan memasuki pembicaraan ini barangkali penggambaran di bawah ini dapat membantu.

Deskripsi singkat kemajemukan pemikiran ke-Islaman individu pasca Muhammadiyah dan NU (Wijdan, Yusdani, dkk,2007: 105-142) dapat diungkapkan sebagaimana tabel 1 .

Pemetaan pluralitas pemikiran keIslaman individu di atas dilakukan berdasarkan indikasi, ide sentral dan kecenderungan tokoh pemikirnya. Dari penggambaran tersebut jelas sekali menunjukkan bahwa corak pemikiran Islam di Indonesia mencerminkan hasil hubungan yang dialektis dengan persoalan; Islam dan modernisasi atau kemoderenan; perjumpaan Islam dengan kebangsaan dan kekuatan negara; dan perjumpaan Islam dengan kekuatan budaya lokal di Indonesia. Dengan kata lain pluralitas pemikiran sosial keagamaan Islam kontemporer di Indonesia pasca Muhammadiyah dan NU di atas sesuai dengan subject matter yang menjadi perhatian utama pemikirnya. Walaupun begitu ada satu mainstream yang menjadi obsesi, yaitu membangun suatu sistem apa yang disebut ( Wijdan, Yusdani, dkk,2007: 147)"keislaman, keindonesiaan dan kemodernan" 
Menuju Beragama Secara Swalayan; Yusdani

Tabel 1

\begin{tabular}{|c|l|l|}
\hline No. & Kategori Pemikiran & \multicolumn{1}{|c|}{ Tokoh Pemikir } \\
\hline 1. & Islam Rasonal & Harun Nasution \\
2. & Islam Saintifik & A.Mukti Ali \\
3. & Islam Kritis & M. Rasjidi \\
4. & Islam Desakralisasi & Nurcholish Madjid \\
5. & Islam Pribumisasi & Abdurrahman Wahid \\
6. & Islam Kultural & Kuntowijoyo \\
7. & Islam Reaktualisasi & Munawir Sjadzali \\
8. & Islam transformatif & Moeslim Abdurrahman dkk \\
9. & Islam Integralis & Ahmad Baiquni dkk \\
10. & Islam Substantif & Azyumardi Azra \\
11. & Islam Dialogis & M. Amin Abdullah \\
12. & Islam Inklusif Pluralis & Alwi Shihab \\
13. & Islam liberal & Ulil Abshar Abdalla \\
14. & Islam Eksklusif & Abu Bakar Ba'asyir dkk \\
15. & Islam ekonomi & Muhammad Syafi'i Antonio dkk, \\
16 & Islam Humanis & Abdurrahman Mas'ud dan PSI UII \\
& & \\
\hline
\end{tabular}

Perkembangan dan dinamika pemikiran Islam individu pasca Muhammadiyah dan $\mathrm{NU}$ di atas telah melahirkan paling tidak tiga generasi pemikir, yaitu generasi pertama adalah generasi Harun, A.Mukti Ali, dan M. Rasjidi. Generasi kedua adalah antara lain Nurcholish Madjid, Abdurrahman Wahid, Kuntowijoyo, M. Dawam Rahardjo, Hidayat Nataatmaja, A. Syafii Maarif, Djohan Effendy, M. Amien Rais, Imaduddin Abdulrahim, Muslim Abdurahman, Munawir Sjadzali, Adi Sasono, Jalaluddin Rahmat, M. Quraisy Shihab, dan lain-lain. Generasi ketiga antara lain adalah Fachry Ali, Azyumardi Azra, M. Amin Abdullah, Alwi Shihab, Masdar Farid Mas'ud, Ulil Abshar Abdallah, Mansur Faqih, Komaruddin Hidayat, Bahtiar Effendy, Munir Mulkhan dan lain-lain ( Wijdan, Yusdani, dkk, 2007: 107).

\section{Dari Pluralitas Menuju Swalayanisasi}

Munculnya multitafsir keagamaan, selain dilandasi oleh semangat teologis dan tafsir atas teks agama juga sebagai respons terhadap perubahan sosial. Pluralitas pemahaman keagamaan merupakan sunnatullah yang tak mungkin terbantahkan dan mustahil pula dilawan dan dihindari. Yang bisa dilakukan terhadapnya adalah saling menghargai, saling mengakui dan adanya sikap toleransi antarsesama (Wijdan, Yusdani,dkk,2007: 142-143).

Wajah gerakan dan pemahaman Islam di Indonesia semakin tampak beragam bersamaan dengan proses liberalisasi dalam berbagai aspek kehidupan. Sebagian di antara mereka ada ( Wijdan, Yusdani, 
dkk,2007: 142-143) yang eksklusif, yang memperjuangkan Islam sebagai dasar berkehidupan secara formal-skriptural. Akan tetapi tidak sedikit yang moderat, yang memperjuangkan secara substantif nilai Islam melalui jalur kultural.

Hanya saja, bersamaan dengan berkembangnya ragam penghayatan dan pemikiran Islam juga muncul sikap-sikap keberagamaan eksklusif yang cenderung menghakimi kelompok lain. Yang lebih memprihatinkan lagi, sikap seperti itu justru ditampilkan oleh kalangan Islam mainstream. Ada panafian terhadap asumsi bahwa ragam pemikiran Islam bukan sebagai sebuah proses dinamis-dialektik antara pemahaman agama dengan realitas sosial yang terus berubah. Acap kali muncul tuduhan terhadap suatu gerakan keagamaan sebagai penyimpangan dan ancaman terhadap stabilitas kehidupan keislaman (Wijdan, Yusdani,dkk,2007: 143).

Seperti yang sering disaksikan, adanya sekelompok orang yang mengatasnamakan umat Islam (AI Makin,2007) menilai pemahaman orang lain sebagai penyimpangan dan penyesatan akidah. Tidak jarang pula mereka menvonis kafir dan menghalalkan darah sesama umat sendiri. Lebih dari itu, mereka meminta kepada pemerintah untuk membekukan seluruh kegiatan gerakan yang dianggap menyimpang itu.

Gejala seperti itu mengisyaratkan tidak akomodatifnya muslim ortodoks-demikian Martin Van Bruinessen menyebutnyaterhadap gerakan Islam minoritas. Dan ini berarti secara hegemonik telah terjadi monopoli tafsir kebenaran. Islam ortodoks tidak menyadari bahwa munculnya pemikiran baru merupakan bentuk ketidakpuasan terhadap keberagamaan dan institusi agama lama yang telah "mapan" ( Wijdan, Yusdani,dkk,2007:143).
Rupanya, dalam masyarakat muslim Indonesia telah tertanam kesadaran bahwa beragama yang benar adalah yang sesuai dengan apa yang telah diwariskan oleh para pendahulunya. Keberagamaan tidak dilihat sebagai proses pencarian menuju kebenaran yang sejati. Keberagamaan juga tidak dikaitkan dengan proses dialogis antara pemeluk agama dengan multikulturalitas yang mengitarinya.

Perlu ditegaskan bahwa timbul dan tenggelamnya pemikiran keagamaan minoritas merupakan gejala yang normal di masyarakat manapun, dan kehadiran mereka mempunyai fungsi yang berguna dalam sebuah dunia sedang berubah dan masa transisi. Di samping itu, pemikiran minoritas biasanya lebih efektif menanamkan nilai-nilai moral di kalangan anggota mereka ketimbang kelompok-kelompok keagamaan mainstream.

Memang, secara sosiologis sebagian dari pemikiran-pemikiran baru dalam agama sebagaimana dicirikan Milton Yinger dalam Religion, Society and the Individual (1975) cenderung memilih eksklusif, menutup diri dari lingkungan sosial, hubungan antaranggota sangat rekat, militan dan berbeda dengan corak keberagamaan mayoritas. Sikap keberagamaan ini sedikit banyak akan mempengaruhi keseimbangan sosial yang diciptakan oleh budaya keagamaan mayoritas yang telah mapan. Atas dasar sikap keberagamaan seperti itu, aliran Islam minoritas dituduh menyimpang (Al Makin,2007) dari ajaran agama Islam dan mendapat perlakuan yang tidak manusiawi.

Dalam konteks itulah pentingnya kaum muslim melihat doktrin Islam tentang keragaman dan kebebasan artikulasi beragama. Alquran secara tegas menkritik sikap arogan dan intoleran terhadap tafsir orang lain dalam kalimat berikut: "Bagi setiap 
Menuju Beragama Secara Swalayan; Yusdani

kelompok mempunyai tujuan, ke sanalah ia mengarahkannya, maka berlombalombalah kamu dalam mengejar kebaikan. Di mana pun kamu berada, Allah akan menghimpun kamu karena Allah berkuasa atas segalanya". (Q.S. al-Baqarah/2:148). "Dan sekiranya Tuhanmu menghendaki, sungguh akan berimanlah manusia di bumi seluruhnya, apakah engkau akan memaksa manusia hingga semuanya beriman?"(Q.S. Yunus: 99).

Islam sangat menghargai perbedaan pemahaman dalam beragama. Pemahaman itu tetap memiliki peluang kebenaran dan keselamatan. Jangankan pengakuan terhadap perbedaan pemahaman dalam satu agama (Islam), dalam Alquran (Q.S. AlBaqarah/2: 62) diisyaratkan adanya keselamatan dalam setiap agama.

Munculnya multitafsir keagamaan, selain dilandasi oleh semangat teologis dan tafsir atas teks agama juga sebagai respons terhadap perubahan sosial. Pluralitas pemahaman keagamaan (Jinan,2004) merupakan sunnatullah yang tak mungkin terbantahkan dan mustahil pula kita lawan dan hindari. Yang bisa dilakukan terhadapnya adalah saling menghargai, saling mengakui dan bersikap toleran.

Oleh karena itu, kaum muslimin Indonesia seharusnya mengutuk segala tindakan kekerasan terhadap kelompok keagamaan minoritas. Kekerasan atas nama monopoli kebenaran yang mengabaikan pluralitas harus ditentang. Pentakfiran, intimidasidan penghakiman (Al Makin, 2007) terhadap aliran minoritas hendaknya dihentikan. Kecuali bila ada bukti bahwa kelompok minoritas ini benar-benar mengganggu tatanan sosial, seperti melakukan tindakan destruktif.

Barang kali penting untuk dikemukakan bahwa tidak mengakui keberadaan suatu paham/aliran keagamaan, sama saja dengan tidak menghargai hak asasi manusia. Keberadaan suatu aliran keagamaan tidak memerlukan pengakuan dari sebuah institusi apapun, termasuk institusi keagamaan.

Seiring dengan itu, dalam sejarahnya pelarangan terhadap berbagai aliran keagamaan dalam kenyataannya tidak efektif. Sebab, hal ini menyangkut keyakinan pribadi seseorang. Keyakinan tidak mungkin ditaklukkan dengan kekuasaan atau kekuatan mayoritas. Hal ini merupakan prinsip kebebasan ekspresi keagamaan atau penafsiran terhadap ajaran agama. Pemaksaan dalam hal agama adalah bertentangan dengan ajaran agama itu sendiri dan secara diametral juga bertentangan dengan martabat manusia sebagai makhluk yang merdeka (Al Makin, 2007).

Menganut paham keagamaan yang berbeda dengan faham mayoritas umat Islam (Wijdan, Yusdani,dkk,2007: 145) merupakan hak yang harus dihormati. Dalam Islam, keberagamaan menuntut ketulusan. Kata "Islam" sendiri berarti tulus dan pasrah. Ini hanya mungkin bila ada kebebasan untuk menerima atau menolak, faham keagamaan lain. Oleh karena itu, setiap bentuk pengurangan dan pembatasan terhadap ekspresi keberagamaan atau kemerdekaan beragama, sedikit atau banyak akan menimbulkan kemunafikan, yang justru mengurangi nilai keislaman itu sendiri.

Islam adalah agama yang memberikan kebebasan kepada para pemeluknya untuk memahami dari berbagai sisi. Ini menggambarkan keluasan Islam yang memungkinkan untuk menampung berbagai produk penafsiran dan pemahaman. Ibarat sebuah supermarket (Jinan,2004), di dalamnya terpampang berbagai jenis produk makanan, 
pakaian, peralatan dan lain-lain. Pengunjung yang masuk ke dalamnya bebas memilih dan menentukan produk apa yang ia kehendaki. Bila pengunjung menghendaki informasi tentang satu jenis produk bisa ditanyakan kepada ahlinya yang ada di tempat itu.

Begitu juga gambaran tentang Islam saat ini dengan segala produk tafsirannya. Kaum muslim perlu menyadari bahwa kini telah terpampang produk tafsir keislaman yang beragam, baik dalam aksi maupun pemikiran. Hal ini meniscayakan umat Islam untuk secara mandiri bebas memilih tafsir mana yang ia suka. Dengan kata lain, hadirnya multitafsir menuntut umat Islam untuk beragama secara "swalayan" (Jinan,2004) yakni, keberagamaan yang dilandasi oleh kemandirian, kebebasan dan tanpa paksaan menentukan pilihan terhadap satu produk penafsiran. Akan tetapi, tentu saja kesukaan terhadap satu pilihan tidak selayaknya disertai dengan penghinaan dan perusakan terhadap pilihan yang lain.

Beragama secara swalayan memungkinkan terwujudnya harapan bahwa perbedaan tafsir keagamaan akan menjadi ladang dialog konstruktif, kreatif dan saling memperkaya pengalamanengetahuan. Juga dapat mengantarkan umat kepada sikap untuk saling memahami. Bukan sebaliknya, perbedaan sebagai lahan untuk menyu-burkan konflik dan saling menyesatkan. Beragama secara swalayan menjanjikan suatu keberagamaan yang egaliter, humanis dan kompetitif dalam kebaikan di tengah hamparan multi produk penafsiran (Jinan, 2004).

\section{Penutup}

Sebagai penutup tulisan ini dapat dikemukakan bahwa secara epistemologis boleh dikatakan bentuk atau varian pemikiran sosial-keislaman kaum muslimin
Indonesia kontemporer dapat dikelompokkan menjadi tiga, yaitu:

Pertama, Islam eksklusif yaitu sikap keagamaan yang memandang bahwa keyakinan, pandangan, pikiran dan prinsip diri sendirilah yang paling benar sementara keyakinan, pandangan, pikiran dan prinsip yang dianut orang lain salah, sesat dan harus dijauhi. Baik bersifat ke luar terhadap agama lain maupun ke dalam yaitu dalam Islam sendiri melalui berbagai mazhab atau aliran dalam berbagai bidang: fiqih, teologi, tasawuf dan lain sebagainya, yang menganggap mazhab atau alirannyalah yang paling benar sedangkan mazhab lainnya salah dan tersesat.

Kedua, Islam Inklusif-Pluralis adalah paham keberagamaan yang didasarkan pada pandangan bahwa agama-agama lain yang ada di dunia ini sebagai yang mengandung kebenaran dan dapat memberikan manfaat serta keselamatan bagi penganutnya. Di samping itu ia tidak semata-mata menunjukkan pada kenyataan tentang adanya kemajemukan, melainkan keterlibatan aktif terhadap kenyataan kemajemukan tersebut.

Ketiga, Islam humanis adalah paham keislaman dengan cara melakukan inisiasi, apresiasi, elaborasi, dan pengembangan berbagai kegiatan yang mengarah pada upaya penampilan Islam yang lebih berpihak kepada pemberdayaan manusia dan masyarakat melalui pendekatan keilmuan

Berdasarkan uraian-uraian di atas jelas suatu kenyataan yang memperlihatkan bahwa variasi kelompok ataupun wilayah pemikiran yang menerima Islam akan segera pula melahirkan variasi versi keislaman. Islam sebagai sebuah nilai, hadir dalam wajahnya yang beragam. Adalah suatu pekerjaan yang amat sulit untuk menyeragamkan penghayatan ke-Islaman 
Menuju Beragama Secara Swalayan; Yusdani

berbagai umatnya. Akan tetapi, yang lebih penting lagi perlu pula disadari adalah tantangan ataupun langkah-langkah yang harus diambil terdapat perbedaan persepsi di antara sesama kalangan Islam.

\section{Daftar Pustaka}

Abdullah, M. Amin.1994. "Muhammadiyah dan Nahdhatul Ulama: Reorientasi Wawasan Pemikiran Keislaman", dalam Yunahar llyas dkk (eds.).1994. Muham-madiyah dan NU Reorientasi Wawasan Keislaman. Yogyakarta: Kerjasama LPPI UMY, LKPSM NU dan PP al-Muhsin, hlm. 170.

.1995. "Islam Indonesia Lebih Pluralistik dan Demokratis", dalam Jurnal Ulumul Qur'an Jurnal IImu dan Kebudayaan No. 3, Vol.VI, Tahun 1995. Jakarta: Lumbaga Studi Agama dan Filsafat. hlm. 70-71.

2002 Dinamika Islam Kultural. Bandung: Mizan.

Abdullah, Taufik.1989. "Islam dan Pembentukan Tradisi di Asia Tenggara: Suatu Perspektif Perbandingan" , dalam Taufik Abdullah dan Sharon Shiddique (eds.). Tradisi dan Kebudayaan Islam di Asia Tenggara. Jakarta: LP3ES), hlm.60,

Abdurrahman, Muslim (ed.).1979. Agama, Budaya dan Masyarakat. Jakarta: Badan Litbang Agama.

.1999."Menafsirkan Islam dalam Tradisi dan Persoalan Umat" dalam Zainuddin Fananie dan M. Thoyibi (editor). 1999. Studi Islam Asia Tenggara.

Surakarta:
Muhammadiyah University Press, hlm.49-72.

Ali, Fachry. 1984. Islam, Ideologi Dunia dan Dominasi Struktural. Bandung: Mizan.

Ali, A. Mukti.1971. Alam Pikiran Islam Modern di Indonesia. Yogyakarta: Yayasan NIDA.

Al Makin, 2007. "Perspektif Lain Soal Pembaruan Islam" http://www. republika. co.id/kolom detail.asp? $\mathrm{id}=279484 \& \mathrm{~kat} \quad \mathrm{id}=16$ accessed Jumat, 19 Januari 2007

Anshari, Endang Saifuddin. 1973. Kritik atas Faham dan Gerakan "Pembaharuan Drs. Nurcholish Madjid. Bandung : Bulan Sabit.

Anwar, M. Syafi'i. 1995. Pemikiran dan Aksi di Indonesia Sebuah Kajian Politik tentang Cendekiawan Muslim Orde Baru. Jakarta: Paramadina.

Arkoun, Mohammed. 1988." The Concept of Authority in Islamic Thought", dalam Klauss Ferdinand and Mehdi Mozaffari (eds.).1988. Islam: State and Society. London: Curzon Press.

Ayoob, Mohammed (ed.).1981. The Politics of Islamic Reassertion. London: Croom Helm.

Ayubi, Nazih.1991. Political Islam: Religion and Politics in the Arab World. London and New York: Routledge.

Azra, Azyumardi.1994. Jaringan Ulama Timur Tengah dan Kepulauan Nusantara Abad XVII dan XVIII. Bandung : Mizan. 
UNISIA, Vol. XXX No. 66 Desember 2007

2000. Islam Substantif. Bandung: Mizan.

Bagir, Zainal Abidin.2002."Pergolakan Pemikiran di Bidang IImu Pengetahuan," dalam Taufik Abdullah (editor kepala).2002. Ensiklopedi Tematis Dunia Islam. Jakarta: P.T. Ichtiar Baru Van Hoeve. HIm. 137160.

Dawalibi, Muhammad Ma'ruf.1965. alMadkhal Ila IIm al-Usual al-Fiqh. Damaskus: Dar al-IIm li al-Malayin.

Dhofier, Zamakhsyari.1982.Tradisi Pesantren.Jakarta: LP3ES.

Geertz, Clifford.1976. Religion of Java. Chicago and London : University of Chicago Press.

Gibbons, Michael T..1987. Interpreting Politics. New York : New York University Press.

Hefner, Robert W..1998. "Islamisasi Kapitalis: tentang Pembentukan Bank Islam Pertama di Indonesia," dalam Mark R. Woodward (ed.).1998. Jalan Baru Islam: Memetakan Paradigma Mutakhir Islam Indonesia terjemahan dari jududl asli Toward $A$ New Paradigm : Recent Developments in Indonesian Islamic Thought oleh Ihsan Ali - Fauzi. Bandung: Mizan, hlm.275.

Hodgson, Marshall G.S..1974. The Venture of Islam Conscience and History in a World Civilization. Chicago and London : The University of Chicago Press.

Jinan, Mutohharun."Mamahami Multitafsir Islam"http://islamlib.com/id/ page. $p h p ?$ page $=$ article $\& i d=430$, accessed, 11 Mei 2007

Madjid, Nurcholish.1970."Keharusan Pembaharuan Pemikiran Islam dan Masalah Integrasi Ummat," Nurcholish Madjid et.al.. Pembaharuan Pemikiran Islam. Jakarta: Islamic Research Center.

.1985." Sekitar Usaha Membangkitkan Etos Intelektualisme Islam di Indonesia" dalam Mukti Ali, dkk., 70 Tahun Prof. Dr. H.M. Rasjidi. Jakarta: Pelita.

.1991."Masalah Tradisi dan Inovasi Keislaman dalam Bidang Pemikiran serta Tantangan dan Harapannya di Indo-nesia,"makalah disampaikan pada Festival Istiqlal, Jakarta, 21-24 Oktober 1991.

.1998." Mencari Akar-Akar Islam Bagi Pluralisme Modern :Pengalaman Indonesia", dalam Mark R.Woodward (Ed.). Jalan Baru Islam Memetakan Paradigma Mutakhir Islam Indonesia terjemahan dari jududl asli Toward $A$ New Paradigm : Recent Developments in Indonesian Islamic Thought oleh Ihsan Ali - Fauzi. Bandung: Mizan, hlm.91

Mas'ud, Abdurrahman. 2003. Menuju Paradigma Islam Humanis. Yogyakarta: Gama Media.

Migdal, Joel S. 1988. Strong Societies and Weak States: State Society Relations and State Capabilities in the Third World. Princeton: Princeton University Press. 
Menuju Beragama Secara Swalayan; Yusdani

Nata, Abuddin. 2001. Peta Keragaman Pemikiran Islam di Indonesia. Jakarta: PT.RajaGarfindo Persada.

Noer,Deliar.1980.Gerakan Modern Islam di Indonesia 1900-1942.Jakarta:LP3ES.

Rachman, Budhy Munawar.1995. "Dari Tahapan Moral ke Periode Sejarah Pemikiran Neo-Modernisme Islam di Indonesia", dalam dalam Jurnal Ulumul Qur'an Jurnal IImu dan Kebudayaan No. 3, Vol.VI, Tahun 1995. Jakarta: Lembaga Studi Agama dan Filsafat. hlm. 6-26.

\section{- - 2001. Islam Pluralis Wacana Kesetaraan Kaum Beriman. Jakarta:Paramadina}

Rahardjo, M Dawam. 1983. "Umat Islam dan Pembaharuan Teologi”. Dalam Bosco Carvallo dan Dasrizal (ed), Aspirasi Umat Islam Indonesia. Jakarta:Leppenas.

. (ed), 1985, Pergulatan Dunia Pesantren: Membangun Dari Bawah, Jakarta: P3M

.1996. "Fundamentalisme", dalam Muhammad Wahyuni Nafis (ed.). Rekonstruksi dan Renungan Religius Islam. Jakarta:Paramadina.

Rakhmat, Jalaluddin. 1989. "Ke mana Arah Pemikiran Islam di Indonesia", Makalah, Jakarta: IAIN Ciputat.

_.1996. Islam Aktual. Bandung :Mizan.

Rasjidi, H.M. 1972, Koreksi Terhadap Drs. Nurcholish Madjid Tentang Sekulerisasi, Jakarta: Bulan Bintang.
Samson, Allan, 1968, Islam in Indonesian Politics, Asian Survey, No:12,Vol.VIII, Desember.

. "Indonesian Since the New Order" 1985. Dalam Ahmad Ibrahim, Sharon Siddique, Yasmin Hussain (eds), Reading on Islam in Southest Asia. Jakarta: Institute of Southeast Asian Studies.

Sasono, Adi. 1985. Moral Agama dan Masalah Kemiskinan. Makalah, tidak diterbitkan.

Sasono, Adi dan Ahmad Rofi'ie.1988. People's Economy, Jakarta: Southeast Asian Forum for Development Alternative.

Sasono, Adi. dan Sritua Arif, 1981, Indonesia: Ketergantungan dan Keterbelakangan, Jakarta: Lembaga Studi Pembangunan.

Shihab, Alwi.1998. Islam Inklusif. Bandung: Mizan.

Simuh.1986. "Pandangan H.M. Rasjidi tentang Kebatinan," dalam alJami'ah. No. 34 Th. 1986, hlm. 2430.

Soekarno. 1964. Dibawah Bendera Revolusi, Vol.1. Jakarta: Panitia Penerbitan Dibawah Bendera Revolusi.

Soemarsono, Soemarso (ed.).. 1978. Mohamad Roem 70 Tahun: Pejuang Perunding. Jakarta: Bulan Bintang.

Sjadzali, Munawir.1984."Pembaharuan: Aplikasi Tanpa Kehilangan Esensi," 
UNISIA, Vol. XXX No. 66 Desember 2007

dalam Panji Masyarakat, No.436, 1 Juli 1984, hlm,12-13.

.1985."Dinamika dan Vitalitas Hukum Islam,"dalam Panji Masyarakat, No.459, 21 Februari 1985, hlm,25-28.

.1985. "Shari'ah: A Dinamic Legal System', makalah disampaikan pada konferensi tentang syari'ah dan kodifikasi, Colombo, Sri Langka, Desember 1985.

.1987."Gejala Krisis Integrasi IImiah di Kalangan IImuwan Islam," dalam Pelita, 24-25 Juli 1987.

_.1988. "Reaktualisasi Ajaran Islam". Dalam Iqbal Abdul Rauf Saimima (ed.), Polemik Reaktualisasi Ajaran Islam Jakarta: Pustaka Panjimas.

Syamsuddin, M. Din. 1992."Tanggapan Terhadap H.Abdurrahman Wahid: Masalah Kepemimpinan Umat" dalam Jawa Pos 26 Agustus 1992, Surabaya, hlm.4.
Tanja Victor, 1979, Himpunan Mahasiswa Islam: Its History and its Place Among Muslim Reformist Movement ini Indonesia. Disertasi Ph.D : Hartford Seminary Foundation.

Wahid, Abdurrahman. 1984. Massa Islam dalam Kehidupan Bernegara dan Berbangsa, Prisma, Edisi Extra.

1985. Merumuskan Hubungan Ideologi Nasional dan Agama, dalam Aula, Mei

. 1989. Pribumi Islam, dalam Muntaha Azhari dan Abdul Mun'im Saleh (eds.), Islam Indonesia Menatap Masa Depan, Jakarta: P3M.

2007. Islamku, Islam Anda, Islam Kita. Jakarta: Wahid Institut

Wijdan, Aden, Yusdani, dkk..2007. Pemikiran dan Peradaban Islam. Yogyakarta: Pusat Studi Islam dan Safira Insania Press. 